\title{
Isolation of $\operatorname{Ins} P_{4}$ and $\operatorname{Ins} P_{6}$ binding proteins from human platelets: Ins $P_{4}$ promotes $\mathrm{Ca}^{2+}$ efflux from inside-out plasma membrane vesicles containing 104 kDa GAP1/P4BP protein
}

\author{
Flavia O'ROURKE*, Eileen MATTHEWS and Maurice B. FEINSTEIN \\ Department of Pharmacology, University of Connecticut School of Medicine, Farmington, CT 06030, U.S.A.
}

\begin{abstract}
A low-density membrane fraction from human platelets contained the plasma membrane marker glycoprotein $\mathrm{Ib}(\mathrm{GpIb})$ and selective binding sites for $\operatorname{Ins} P_{4}$ and $\operatorname{Ins} P_{6}$. It was separated from the bulk of Ins $P_{3}$-receptor-containing membranes, but was heterogeneous, probably also containing surface-connected canalicular system and some lighter elements of the internal dense tubule system. After loading with calcium oxalate and re-centrifugation on Percoll gradients, this mixed fraction was subfractionated into light membranes containing all of the $\mathrm{GpIb}$, high-affinity Ins $P_{4}$ binding sites $\left(K_{\mathrm{D}}=18 \mathrm{nM}\right)$ and phosphatestimulated $\mathrm{Ca}^{2+}$ transport activity. Ins $P_{4}\left(\mathrm{EC}_{50} 0.6 \mu \mathrm{M}\right)$, but not Ins $P_{3}$ or Ins $P_{6}$, released up to $35 \%$ of the accumulated $\mathrm{Ca}^{2+}$ from these vesicles, which were shown to be inside-out plasma membrane vesicles by a biotinylation labelling technique and selective
\end{abstract}

removal of right-side-out plasma membrane vesicles with streptavidin-agarose. Most of the $\operatorname{Ins} P_{4}$, and all of the $\operatorname{Ins} P_{6}$, binding was present in the much denser calcium oxalate-loaded subfractions, which were free of GpIb. Ins $P_{6}$ binding activity was chromatographically purified as a $116 \mathrm{kDa}$ protein $\left(K_{\mathrm{D}}\right.$ for Ins $\left.P_{6}=5.9 \mathrm{nM}\right)$, with an amino acid content and two internal peptide sequences identical to those of $116 \mathrm{kDa}$ vinculin. A $104 \mathrm{kDa} \operatorname{Ins} P_{4}$ binding protein $\left(K_{\mathrm{D}}\right.$ for Ins $\left.P_{4}=12 \mathrm{nM}\right)$, probably identical to GAP1 $1^{\text {IP4BP }}$ described by Cullen, Hsuan, Truong, Letcher, Jackson, Dawson and Irvine [(1995) Nature (London) 376, 527-530], was also isolated. This Ins $P_{4}$ receptor may mediate $\mathrm{Ca}^{2+}$ influx in platelets that occurs subsequent to receptorstimulated production of $\operatorname{Ins} P_{3}$ and unloading of internal $\mathrm{Ca}^{2+}$ stores.

\section{INTRODUCTION}

The importance of $\operatorname{Ins}(1,4,5) P_{3}$ as a second messenger for intracellular $\mathrm{Ca}^{2+}$ signalling is well documented in many cell types, including platelets. Other inositol phosphates such as Ins $(1,3,4,5) P_{4}$ and $\operatorname{Ins} P_{6}$ are found in many cells, and it has been suggested that they are also involved in signal transduction processes, including the control of cytosolic $\mathrm{Ca}^{2+}$ levels and clathrin assembly, but their specific functions are largely either unclear or unknown. Ins $P_{4}$ is formed intracellularly by the phosphorylation of $\operatorname{Ins} P_{3}$, and $\operatorname{Ins} P_{4}$ binding sites have been identified in cerebellum [1,2], HL-60 cells [3], adrenal cortex [4], liver [5] and platelets [6]. A specific Ins $P_{4}$ receptor has been purified from pig platelet plasma membranes [7], and recently its cDNA was sequenced and shown to code for a member of the GTPase-activating protein (GAP) protein family, and designated as GAP $1^{\text {IP4BP }}$ [8]. Ins $P_{4}$ has various effects on $\mathrm{Ca}^{2+}$ in cells; e.g. it may (1) control $\mathrm{Ca}^{2+}$ entry into sea urchin eggs as a mechanism to replenish internal $\mathrm{Ca}^{2+}$ stores [9], (2) contribute to the release of $\mathrm{Ca}^{2+}$ from internal stores in brain [10], (3) enhance $\mathrm{Ca}^{2+}$ uptake into internal storage sites [11], and (4) activate a $\mathrm{Ca}^{2+}$ permeable channel in endothelial cell plasma membranes [12]. Several inositol polyphosphate binding proteins that bind $\operatorname{Ins} P_{4}$, but with lesser affinity than for $\operatorname{Ins} P_{6}$, have also been described [13-15].

Ins $P_{3}$ releases $\mathrm{Ca}^{2+}$ from vesicles derived from the internal membrane system (internal dense tubule system; DTS) of human platelets [16-20], but nothing is known about the functions of either Ins $P_{4}$ or $\operatorname{Ins} P_{6}$ in platelets. Here we report on the binding of Ins $P_{4}$ and Ins $P_{6}$ to platelet membranes, and the purification of a $104 \mathrm{kDa} \operatorname{Ins} P_{4}$ receptor protein and its separation from a $116 \mathrm{kDa} \operatorname{Ins} P_{6}$ binding protein. We also show that the $\operatorname{Ins} P_{4}$ binding protein is found in two fractions, with the majority in a membrane fraction containing the $\operatorname{Ins} P_{6}$ binding protein and exhibiting oxalate-stimulated $\mathrm{Ca}^{2+}$ transport. Lastly, we demonstrate the ability of Ins $P_{4}$ to increase $\mathrm{Ca}^{2+}$ efflux across insideout membrane vesicles derived from the plasma membrane fraction of human platelets. Therefore the plasma membrane Ins $P_{4}$ receptor may mediate $\mathrm{Ca}^{2+}$ influx in agonist-stimulated platelets, which occurs subsequent to the production of $\operatorname{Ins} P_{3}$ and unloading of internally sequestered $\mathrm{Ca}^{2+}$ stores by $\operatorname{Ins} P_{3}[21]$.

\section{MATERIALS AND METHODS}

\section{Materials}

Radiolabelled [ $\left.{ }^{3} \mathrm{H}\right] \operatorname{Ins} P_{4}(17 \mathrm{Ci} / \mathrm{mmol}), \operatorname{Ins} P_{6}(21 \mathrm{Ci} / \mathrm{mmol})$ and ${ }^{45} \mathrm{CaCl}_{2}$ were from New England Nuclear, $\left[{ }^{3} \mathrm{H}\right] \mathrm{Ins} P_{3}$ (35 Ci/mmol) was purchased from Amersham, and non-radioactive inositol phosphates were from the Rhode Island Chemical Group (University of Rhode Island, Kingston, RI, U.S.A.). The sources of other reagents were as follows: monoclonal antibody against glycoprotein $\mathrm{Ib}(\mathrm{GpIb})$ (Immunotech), peroxidaselabelled second antibodies (Boehringer Mannheim), sulphosuccinimidyl-6-(biotin amido)hexanoate (sulpho-NHS-LCbiotin), peroxidase-labelled streptavidin and Immunopure immobilized streptavidin linked to agarose (Pierce Chemical Co.), chemiluminescence reagents (Kirkegaard and Perry), concanavalin A (ConA)-agarose (Sigma Chemical Co.).

\section{Assays of $\mathrm{Ca}^{2+}$ uptake and release in platelet membrane vesicles}

Platelets obtained from the Connecticut Red Cross were washed in buffer containing $0.135 \mathrm{M} \mathrm{NaCl}, 5 \mathrm{mM} \mathrm{KCl}, 10 \mathrm{mM}$ Hepes,

Abbreviations used: GAP, GTPase-activating protein; DTS, dense tubule system; Gplb, glycoprotein Ib; sulpho-NHS-LC-biotin, sulphosuccinimidyl-

6-(biotin amido)hexanoate; DTT, dithiothreitol; ConA, concanavalin A; SCCS, surface-connected canalicular system.

* To whom correspondence should be addressed. 
$\mathrm{pH} 7.6$, and then washed in $0.125 \mathrm{M} \mathrm{NaCl}, 5 \mathrm{mM} \mathrm{KCl}, 10 \mathrm{mM}$ Pipes, 0.2 mM EGTA, pH 6.8. Washed platelets were sonicated, and membrane fractions were separated on a $12 \mathrm{ml}$ continuous $40 \%$ Percoll gradient by the method of O'Rourke and Feinstein [17] to yield $1.0 \mathrm{ml}$ fractions numbered $1-11$ from the top of the gradient. Membranes from the Percoll gradients were washed twice in a buffer of $100 \mathrm{mM} \mathrm{KCl}, 10 \mathrm{mM}$ Hepes, $5 \mathrm{mM} \mathrm{MgCl}$, $0.5 \mathrm{mM}$ PMSF, $0.5 \mathrm{mM}$ dithiothreitol (DTT) and $10 \mu \mathrm{M}$ each of pepstatin and leupeptin. Membranes $(0.2 \mathrm{mg}$ of protein $/ \mathrm{ml})$ were incubated for $1 \mathrm{~h}$ at $23{ }^{\circ} \mathrm{C}$ in $\mathrm{Ca}^{2+}$ uptake buffer, i.e. the above wash buffer plus $0.5 \mu \mathrm{Ci} / \mathrm{ml}^{45} \mathrm{CaCl}_{2}, 0.56 \mathrm{mM}$ EGTA, $0.4 \mathrm{mM}$ $\mathrm{CaCl}_{2}, 10 \mathrm{mM}$ potassium phosphate and $2 \mathrm{mM}$ disodium ATP (free $\mathrm{Ca}^{2+}=1 \mu \mathrm{M}$ ). Duplicate aliquots were added at various time points to $25 \mu \mathrm{l}$ of a formalin/EDTA solution [17] to immediately stop all transport, and centrifuged for $2 \mathrm{~min}$ at $463000 \mathrm{~g}$ in a TL-100 centrifuge. Supernatants were aspirated and the pellets were extracted with $50 \mu 1$ of $50 \%$ (w/v) trichloroacetic acid and assayed for ${ }^{45} \mathrm{Ca}^{2+}$ by liquid scintillation counting. $\mathrm{Ca}^{2+}$ release induced by $\operatorname{Ins} P_{4}$ was studied using vesicles preloaded with ${ }^{45} \mathrm{Ca}^{2+}$. These reactions were also stopped by formalin/EDTA and the pellets analysed for ${ }^{45} \mathrm{Ca}^{2+}$ as above.

\section{Separation of plasma membrane vesicles from internal membrane vesicles by loading with calcium oxalate}

Fractions 1-3 from Percoll gradients were pooled and incubated for $1 \mathrm{~h}$ at $25{ }^{\circ} \mathrm{C}$ in $\mathrm{Ca}^{2+}$ uptake buffer (without ${ }^{45} \mathrm{Ca}^{2+}$ ) plus $5 \mathrm{mM}$ potassium oxalate and subfractionated into 'heavy' and 'light' membrane fractions by centrifugation on a $40 \%$ Percoll gradient for $50 \mathrm{~min}$ at $40000 \mathrm{~g}$ in a Sorvall centrifuge using an SS34 rotor. One-quarter of the total membranes were incubated in medium with ${ }^{45} \mathrm{Ca}^{2+}$, which thereby served as a marker to locate on the gradient those membrane subfractions that were capable of oxalate-stimulated $\mathrm{Ca}^{2+}$ uptake. Fractions of $1.0 \mathrm{ml}$ each, from the top of the gradient down, were removed and designated as subfractions 1a-11a. Non-radioactive subfractions isolated in the same way were washed twice and resuspended in $\mathrm{Ca}^{2+}$ uptake buffer supplemented with $10 \mathrm{mM}$ phosphate, $1 \mathrm{mM}$ ATP and ${ }^{45} \mathrm{Ca}^{2+}$, and incubated for $60 \mathrm{~min}$ at $23{ }^{\circ} \mathrm{C}$. The effect of Ins $P_{4}$ on ${ }^{45} \mathrm{Ca}^{2+}$ accumulation by these vesicles was measured as described above.

\section{Ligand binding assays}

Platelet sonicates were centrifuged on $12 \mathrm{ml}$ Percoll gradients, the upper $3.0 \mathrm{ml}$ (fractions 1-3) of the gradients was pooled, and $2.0 \mathrm{ml}$ fractions were collected from the remaining gradient. All membranes were washed and resuspended at $1.0 \mathrm{mg}$ of protein $/ \mathrm{ml}$. The binding of radioactive $\operatorname{Ins} P_{4}, \operatorname{Ins} P_{6}$ and $\operatorname{Ins} P_{3}$ to membranes, at equilibrium, was evaluated over the $\mathrm{pH}$ range 5.8-8.3 at $4{ }^{\circ} \mathrm{C}$. A pH 5.8 buffer $(25 \mathrm{mM}$ Mes, $1 \mathrm{mM}$ EDTA, $0.5 \mathrm{mM}$ DTT and $0.5 \mathrm{mM}$ PMSF) was optimal for $\left[{ }^{3} \mathrm{H}\right] \operatorname{Ins} P_{4}$ binding, whereas $\left[{ }^{3} \mathrm{H}\right] \operatorname{Ins} P_{3}$ binding was greatest in bicarbonate buffer at $\mathrm{pH} 8.3$ [17] and $\left[{ }^{3} \mathrm{H}\right] \mathrm{Ins} P_{6}$ binding, which is unaffected by $\mathrm{pH}$, was measured at $\mathrm{pH}$ 7.4. Non-specific binding was measured in the presence of $1 \mu \mathrm{M}$ of the appropriate nonradioactive inositol phosphate. Duplicate aliquots of $100 \mu 1$ were centrifuged for $4 \mathrm{~min}$ in a Beckman TL-100 centrifuge at $463000 \mathrm{~g}$. Supernatants were aspirated and the pellets were extracted with $50 \mu \mathrm{l}$ of $50 \%$ trichloroacetic acid. [ $\left.{ }^{3} \mathrm{H}\right]$ Inositol phosphate in the extracts was assayed by liquid scintillation counting.

$\left[{ }^{3} \mathrm{H}\right] \mathrm{Ins} P_{4}$ binding to solubilized receptor protein was assayed using aliquots $(75 \mu \mathrm{l})$ of chromatographic fractions that were diluted with an equal volume of $\mathrm{pH} 5.8$ Mes buffer without CHAPS and incubated with $\left[{ }^{3} \mathrm{H}\right] \mathrm{Ins} P_{4}$ for $15 \mathrm{~min}$ at $4{ }^{\circ} \mathrm{C}$, followed by addition of $8 \mu \mathrm{l}$ of rabbit $\operatorname{IgG}(50 \mathrm{mg} / \mathrm{ml})$ as carrier. Non-specific binding was determined in the presence of $1 \mu \mathrm{M}$ non-radioactive $\operatorname{Ins} P_{4}$. Duplicate aliquots of $75 \mu \mathrm{l}$ were added to $100 \mu \mathrm{l}$ of $30 \%$ poly(ethylene glycol) 6000 in pH 5.8 Mes buffer to precipitate proteins. The samples were held at $4{ }^{\circ} \mathrm{C}$ for $10 \mathrm{~min}$, followed by centrifugation at $463000 \mathrm{~g}$ in a TL-100 Beckman centrifuge for $10 \mathrm{~min}$. The protein pellets were extracted with $50 \%$ trichloroacetic acid and centrifuged to obtain supernatants that were assayed by liquid scintillation counting. Similarly, binding of $\left[{ }^{3} \mathrm{H}\right] \operatorname{Ins} P_{6}$ was measured at $\mathrm{pH}$ 7.4. All ligand binding data were analysed using the non-linear regression program BIOSOFT (Elsevier) and displayed as Scatchard plots.

\section{Labelling of the platelet cell surface by sulpho-NHS-LC-biotin}

All procedures were carried out at $25^{\circ} \mathrm{C}$. Three units of platelets (1 unit is $60 \mathrm{ml}$ of platelet-rich plasma) were washed with $0.135 \mathrm{M} \mathrm{NaCl}, 5 \mathrm{mM} \mathrm{KCl}, 10 \mathrm{mM}$ Hepes, $\mathrm{pH}$ 7.6, and then with $0.125 \mathrm{M} \mathrm{NaCl}, 5 \mathrm{mM} \mathrm{KCl}, 10 \mathrm{mM}$ Pipes, $0.2 \mathrm{mM}$ EGTA, $\mathrm{pH}$ 6.8. The platelet pellets were resuspended in PBS $(138 \mathrm{mM}$ $\mathrm{NaCl}, 1.2 \mathrm{mM} \quad \mathrm{KH}_{2} \mathrm{PO}_{4}, 8.1 \mathrm{mM} \quad \mathrm{Na}_{2} \mathrm{HPO}_{4}, 2.7 \mathrm{mM} \mathrm{KCl}$, $\mathrm{pH}$ 7.4) with $5 \mathrm{mM}$ sulpho-NHS-LC-biotin and incubated for $45 \mathrm{~min}$. After two washes with PBS to remove unreacted biotin, the platelets were resuspended in $2 \mathrm{ml}$ of ice-cold buffer containing $100 \mathrm{mM} \mathrm{KCl}, 10 \mathrm{mM}$ Hepes, $5 \mathrm{mM} \mathrm{MgCl}_{2}, 0.5 \mathrm{mM}$ DTT, $0.5 \mathrm{mM}$ PMSF, $10 \mu \mathrm{M}$ leupeptin and $10 \mu \mathrm{M}$ pepstatin, $\mathrm{pH}$ 7.1. The platelets were sonicated and the membranes were washed with the above buffer and then incubated with Immunopure immobilized streptavidin for $1 \mathrm{~h}$. The suspensions were centrifuged for $10 \mathrm{~min}$ at $12000 \mathrm{~g}$ to remove the biotin-labelled membranes adhered to streptavidin-agarose beads. Unlabelled cells, treated in the same manner, served as a control. Thus the net result was to specifically remove biotin-labelled (right-sideout) vesicles, leaving inside-out vesicles plus internally derived membranes in the suspension. The latter were loaded with calcium oxalate, as described above, followed by centrifugation on a $40 \%$ Percoll gradient. Membrane subfractions (1b-11b) were washed and assayed for $\mathrm{GpIb},{ }^{45} \mathrm{Ca}^{2+}$ uptake in the presence of phosphate, and release of $\mathrm{Ca}^{2+}$ by $\operatorname{Ins} P_{4}$. The membrane vesicles that were not removed by streptavidinagarose were subjected to SDS/PAGE ( $7.5 \%$ gels), blotting with peroxidase-labelled streptavidin and detection by enhanced chemiluminescence.

\section{Western blotting for Gplb}

Membrane proteins separated by SDS/PAGE (7.5\% gels) were semi-dry blotted on to Immobilon nylon membranes and incubated for $45 \mathrm{~min}$ with a blocking solution of $5 \%$ powdered milk and $1 \%$ goat serum in PBS/Tween (i.e. PBS, pH 7.4, with $0.1 \%$ Tween 20). The blots were incubated with a 1:10000 dilution of anti-GP1b monoclonal antibody in blocking buffer for $1 \mathrm{~h}$ at $23{ }^{\circ} \mathrm{C}$, and then washed with PBS/Tween for $2 \times 15 \mathrm{~min}$ and $3 \times 5 \mathrm{~min}$. The blots were incubated for $45 \mathrm{~min}$ with peroxidaselabelled goat anti-mouse $\mathrm{IgG}_{1}$ diluted 1:15000 in PBS/Tween, followed by washing as described for the first antibody. The washed immunoblots were incubated with enhanced chemiluminescence reagent and exposed to BioMax-MR X-ray film (Kodak) for $1 \mathrm{~min}$. The images were quantified by a Molecular Dynamics laser densitometer using Image Quant software.

\section{Purification of $\operatorname{Ins} \boldsymbol{P}_{4}$ and $\operatorname{lns} \boldsymbol{P}_{6}$ binding proteins}

All procedures were carried out at $4{ }^{\circ} \mathrm{C}$. Platelet membrane fractions 1-3 (80-100 $\mathrm{mg}$ of protein) were pooled from Percoll gradients and washed twice with buffer containing $1 \mathrm{M} \mathrm{NaCl}$, 
$20 \mathrm{mM}$ bicarbonate, $10 \mu \mathrm{M}$ each of leupeptin and pepstatin, $0.5 \mathrm{mM}$ PMSF, $0.5 \mathrm{mM}$ DTT, $\mathrm{pH} 7.4$, to remove non-integral membrane proteins. The membranes were washed twice more in the same buffer without added $\mathrm{NaCl}$ and then solubilized in $50 \mathrm{ml}$ of the same buffer plus $5 \%$ CHAPS. The protease inhibitors and DTT stabilized the binding activity of detergentsolubilized protein. The solubilized membranes were stirred for $1 \mathrm{~h}$ and centrifuged for $1 \mathrm{~h}$ at $40000 \mathrm{~g}$ to remove particulate matter. The supernatant was passed through a $5 \mathrm{ml}$ ConAagarose column to remove glycoproteins. The ConA-agarose flow-through was adjusted to $0.025 \mathrm{M} \mathrm{NaCl}$ and $\mathrm{pH} 5.8$ with Mes and applied to an HPLC anion-exchange column (Supelco) at a flow rate of $1 \mathrm{ml} / \mathrm{min}$. Proteins were eluted with a gradient of $0.025-1.0 \mathrm{M} \mathrm{NaCl}$ in $1 \%$ CHAPS, $1 \mathrm{mM}$ EDTA, $25 \mathrm{mM}$ Mes at $\mathrm{pH}$ 5.8. Fractions $(1.0 \mathrm{ml})$ were collected and assayed for binding of $\left[{ }^{3} \mathrm{H}\right] \operatorname{Ins} P_{4}$ and $\left[{ }^{3} \mathrm{H}\right] \operatorname{Ins} P_{6}$. The peak $\left[{ }^{3} \mathrm{H}\right] \operatorname{Ins} P_{4}$ and $\left[{ }^{3} \mathrm{H}\right] \mathrm{Ins} P_{6}$ binding fractions were pooled, concentrated and dialysed by a Centricon device (molecular mass cut-off of $30 \mathrm{kDa}$ ) and then applied to a heparin-TSK HPLC column (ToyoHaas) in the elution buffer described above (with $25 \mathrm{mM} \mathrm{NaCl}$ ) at a flow rate of $0.2 \mathrm{ml} / \mathrm{min}$. $\left[{ }^{3} \mathrm{H}\right] \mathrm{Ins} P_{6}$ binding activity was all found in the heparin column flow-through, which was concentrated using a $30 \mathrm{kDa}$ cut-off Centricon device and chromatographed on an HPLC gel filtration column (Zorbax G450; DuPont). Protein adsorbed on to the heparin-TSK column was eluted with a $0.025-1.0 \mathrm{M} \mathrm{NaCl}$ gradient at a flow rate of $0.5 \mathrm{ml} / \mathrm{min}$ and collected in $0.5 \mathrm{ml}$ fractions. The peak $\left[{ }^{3} \mathrm{H}\right] \mathrm{Ins} P_{4}$ binding fractions were pooled, concentrated and dialysed overnight in elution buffer without $\mathrm{NaCl}$, and assayed for ligand binding and analysis by SDS/PAGE.

\section{RESULTS}

The various inositol phosphates bound to sonicated platelet membranes with different dependencies on $\mathrm{pH}$. Ins $P_{3}$ binding was greatest at alkaline $\mathrm{pH}$ [17], the binding of Ins $P_{4}$ was greatest at moderately acid $\mathrm{pH}$, whereas $\operatorname{Ins} P_{6}$ binding was virtually unaffected from $\mathrm{pH} 5.8$ to 8.3 (results not shown). Membranes isolated by centrifugation on Percoll gradients were divided into

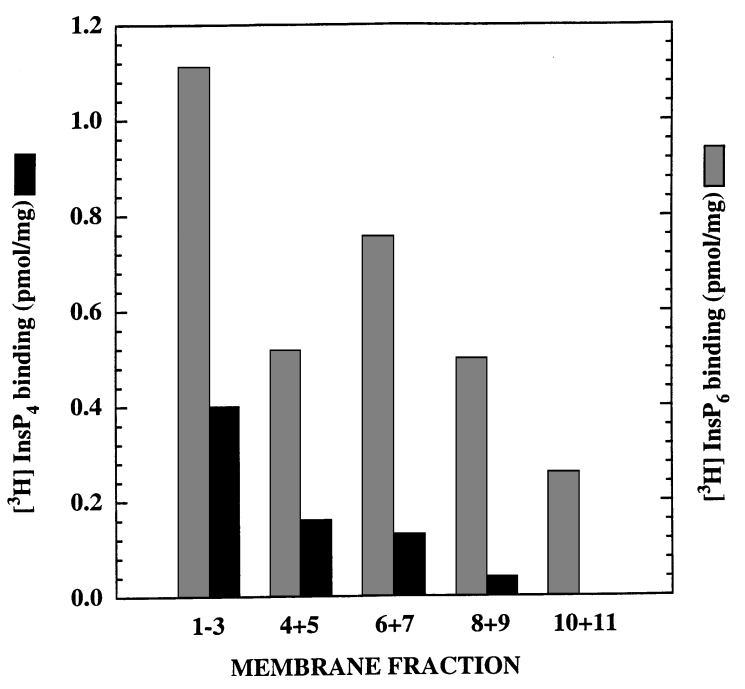

Figure 1 Binding of inositol phosphates to platelet membrane fractions

Membrane fractions (100 $\mu \mathrm{g}$ of protein) from a Percoll gradient were incubated with $10 \mathrm{nM}$ $\left[{ }^{3} \mathrm{H}\right] \operatorname{lns} \mathrm{P}_{4}$ or $\left[{ }^{3} \mathrm{H}\right] \mathrm{nns} \mathrm{P}_{6}$ and specific binding was measured as described in the Materials and methods section. Data are from a single experiment repeated three times with similar results.

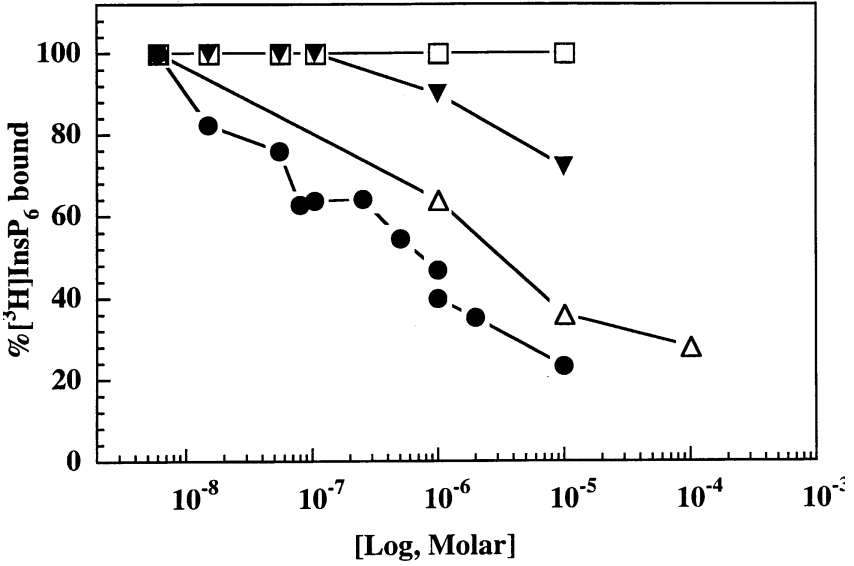

Figure 2 Displacement of bound $\left[{ }^{3} \mathrm{H}\right] \mathrm{Ins} P_{6}$ from platelet membranes

Membrane fractions $1-3$ (50 $\mu \mathrm{g}$ of protein) were incubated with $5 \mathrm{nM}\left[{ }^{3} \mathrm{H}\right] \mathrm{Ins} P_{6}$ and various concentrations of non-radioactive displacer ligands, and analysed for bound radioactive ligand (\% of control) as described in the Materials and methods section: $P$, non-radioactive Ins $P_{6}$; $\triangle$, heparin; $\boldsymbol{\nabla}, \operatorname{Ins} P_{4} ; \square, \operatorname{Ins} P_{3} . I_{50}$ values for displacement: Ins $P_{6}, 100 \mathrm{nM}$; heparin, $5 \mu \mathrm{M}$; Ins $P_{4}$ and $\operatorname{Ins} P_{3},>10 \mu \mathrm{M}$.

$12 \times 1 \mathrm{ml}$ fractions and assayed for $\left[{ }^{3} \mathrm{H}\right] \operatorname{Ins} P_{4}$ and $\left[{ }^{3} \mathrm{H}\right] \mathrm{Ins} P_{6}$ binding. A total of $52 \%$ of the total $\left[{ }^{3} \mathrm{H}\right] \mathrm{Ins} P_{4}$ binding was found in combined fractions $1-3$, with a lesser amount in fractions $4+5$ $(21 \%)$ and $5+6(17 \%)$ (Figure 1). Peak $\left[{ }^{3} \mathrm{H}\right] \operatorname{Ins} P_{6}$ binding $(37 \%)$ was in fractions $1-3$ (Figure 1). In contrast, most $(50 \%)$ of Ins $P_{3}$ binding was concentrated in the heavier fractions $4+5$ [17,22], suggesting that the $\operatorname{Ins} P_{4}$ and $\operatorname{Ins} P_{6}$ receptors might reside in a different membrane compartment than the $\operatorname{Ins} P_{3}$ receptor. The binding of $\left[{ }^{3} \mathrm{H}\right] \operatorname{Ins} P_{4}$ was highly specific for the $\operatorname{Ins}(1,3,4,5) P_{4}$ isomer; e.g. $\mathrm{IC}_{50}$ values for displacement of $10 \mathrm{nM}\left[{ }^{3} \mathrm{H}\right] \mathrm{Ins} P_{4}$ from fractions $1-3$ were $40 \mathrm{nM}$ for non-radioactive $\operatorname{Ins} P_{4}, 8 \mu \mathrm{M}$ for $\operatorname{Ins}(1,4,5,6) P_{4}, 50 \mu \mathrm{M}$ for $\operatorname{Ins}(1,3,4,6) P_{4}, 30 \mu \mathrm{M}$ for $\operatorname{Ins} P_{3}$ and $6 \mu \mathrm{M}$ for Ins $P_{6}$. The $\mathrm{IC}_{50}$ for heparin was $1 \mu \mathrm{M}$. Direct binding of $\left[{ }^{3} \mathrm{H}\right] \operatorname{Ins} P_{4}$ to membrane fractions $1-3$, measured over a concentration range of $5-50 \mathrm{nM}$ radioactive ligand, yielded an average $K_{\mathrm{D}}$ of $18 \mathrm{nM}$ (results not shown). Similarly, the displacement of $5 \mathrm{nM}\left[{ }^{3} \mathrm{H}\right] \operatorname{Ins} P_{6}$ from membranes was highly specific; i.e. $\mathrm{IC}_{50} \mathrm{~s}$ were $100 \mathrm{nM}$ for $\operatorname{Ins} P_{6},>10 \mu \mathrm{M}$ for $\operatorname{Ins} P_{4}$ and Ins $P_{3}$, and $5 \mu \mathrm{M}$ for heparin (Figure 2).

To test for functions of $\operatorname{Ins} P_{4}$ and $\operatorname{Ins} P_{6}$, we isolated membrane vesicle fractions $1-3$ and $4+5$ from 17 individual batches of human platelets and loaded them with ${ }^{45} \mathrm{Ca}^{2+}$ in phosphatecontaining buffer plus ATP. Ins $P_{4}$ released $15-25 \%$ of the ${ }^{45} \mathrm{Ca}^{2+}$ from fractions $1-3$, but had little or no effect on fractions $4+5$ (maximum $3-5 \%$ release by $10 \mu \mathrm{M}$ Ins $P_{4}$ ). In contrast, $5 \mu \mathrm{M}$ Ins $P_{3}$ released $25-40 \%$ of the accumulated ${ }^{45} \mathrm{Ca}^{2+}$ from fractions $4+5$ (results not shown). ${ }^{45} \mathrm{Ca}^{2+}$ was released from fractions $1-3$ by both $\operatorname{Ins} P_{3}$ and Ins $P_{4}$, but their effects were additive, suggesting that each acted on different compartments. For example, the maximum release induced by a combination of $\operatorname{Ins} P_{3}+\operatorname{Ins} P_{4}$ was $40 \%$, the maximum by Ins $P_{3}$ alone was $15 \%$ and the maximum by Ins $P_{4}$ alone was $25 \%$. Ins $P_{6}(10-20 \mu \mathrm{M})$ did not release $\mathrm{Ca}^{2+}$ from any vesicles.

Fractions 1-3 from the Percoll gradients also showed some $\left[{ }^{3} \mathrm{H}\right] \mathrm{Ins} P_{3}$ binding and oxalate-stimulated $\mathrm{Ca}^{2+}$ uptake (results not shown). The latter is a specific characteristic of the $\mathrm{Ca}^{2+}$ transport system of the internal platelet membranes, but not that of the plasma membrane [23]. These findings, and the release of $\mathrm{Ca}^{2+}$ by both $\operatorname{Ins} P_{4}$ and $\operatorname{Ins} P_{3}$, indicated that fractions 1-3 


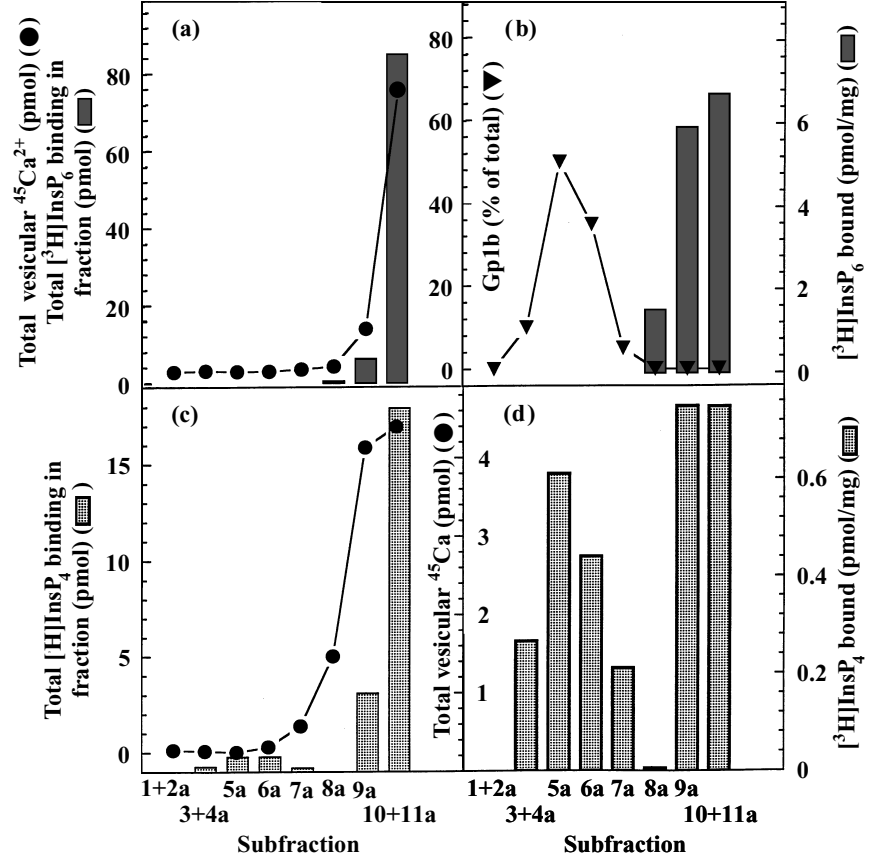

Figure 3 Binding of $\left[{ }^{3} \mathrm{H}\right]$ Ins $P_{4}$ and $\left[{ }^{3} \mathrm{H}\right] \mathrm{Ins} P_{6}$ to platelet membrane subfractions obtained after loading with calcium oxalate

Membrane fractions 1-3 were loaded with ${ }^{45} \mathrm{Ca}^{2+}$ in the presence of $5 \mathrm{mM}$ oxalate and $1 \mathrm{mM}$ ATP and recentrifuged on a Percoll gradient (see the Materials and methods section). Subfractions 1a-11a (30 $\mu \mathrm{g}$ of protein) were assayed for binding of $\left[{ }^{3} \mathrm{H}\right] \mathrm{Ins} P_{4}$ and $\left[{ }^{3} \mathrm{H}\right] \mathrm{Ins} P_{6}$, and for content of ${ }^{45} \mathrm{Ca}^{2+}$ and Gplb. (a) Bar graph: binding of $\left[{ }^{3} \mathrm{H}\right]\left[\mathrm{ns} P_{6}\right.$; ${ }^{4}{ }^{45} \mathrm{Ca}^{2+}$ uptake. (b) Bar graph: specific activity of $\left.{ }^{3} \mathrm{H}\right] \mathrm{Ins} P_{6}$ binding; $\boldsymbol{\nabla}$, GP1b content of $10 \mu \mathrm{g}$ membrane protein samples (average of three experiments). (c) Bar graph: binding of $\left[{ }^{3} \mathrm{H}\right] \mathrm{Ins} P_{4} ; \mathbf{0},{ }^{45} \mathrm{Ca}^{2+}$ uptake. (d) Specific activity of Ins $P_{4}$ binding

contained elements of both the surface and internal membranes. Plasma membranes were further separated from vesicles derived from the internal membrane system by taking advantage of the tendency of calcium oxalate to accumulate and precipitate within internal membrane vesicles, thereby increasing their specific gravity. This was confirmed by loading fraction $1-3$ vesicles with ${ }^{45} \mathrm{Ca}^{2+}$ in the presence of $5 \mathrm{mM}$ oxalate and $1 \mathrm{mM}$ ATP and recentrifuging them on a Percoll gradient. ${ }^{45} \mathrm{Ca}^{2+}$ and $\operatorname{Ins} P_{6}$ binding activity were found virtually exclusively in fractions $8 \mathrm{a}-11 \mathrm{a}$, corresponding to a much denser part of the gradient (Figures $3 \mathrm{a}$ and $3 \mathrm{~b}$ ), whereas Gplb was entirely confined to the lighter membranes in subfractions $3 a-7 a$ (Figure $3 b$ ). The dense membrane fractions also contained $90 \%$ of the total $\operatorname{Ins} P_{4}$ binding activity (Figure 3c), but the gradient had two areas with high specific activity for Ins $P_{4}$ binding, i.e. the GpIb-containing fractions $3 \mathrm{a}-7 \mathrm{a}$ and the ${ }^{45} \mathrm{Ca}^{2+}$-labelled heavy fractions that contained all of the $\operatorname{Ins} P_{6}$ binding activity (Figure $3 \mathrm{~d}$ ). In the latter fractions we determined that $\operatorname{Ins} P_{4}$ and $\operatorname{Ins} P_{6}$ were binding to different entities, because $200 \mathrm{nM} \operatorname{Ins} P_{6}$ did not displace bound $\left[{ }^{3} \mathrm{H}\right] \operatorname{Ins} P_{4}$ (Ins $P_{4}$ present at $10 \mathrm{nM} ; K_{\mathrm{D}}=12 \mathrm{nM}$ ) and $10 \mu \mathrm{M}$ Ins $P_{4}$ did not displace bound $\left[{ }^{3} \mathrm{H}\right] \mathrm{Ins} P_{6}$ (the latter present at $\left.10 \mathrm{nM} ; K_{\mathrm{D}}=18 \mathrm{nM}\right)$.

The inositol phosphates were then tested for their effects on $\mathrm{Ca}^{2+}$ release from vesicles of the 'light' membrane fractions obtained after calcium oxalate loading as described above. Membrane fractions 1-3 were loaded with calcium oxalate (but no ${ }^{45} \mathrm{Ca}^{2+}$ ) and centrifuged on Percoll to obtain fractions 1a-11a. The membrane fractions were individually washed and resus-

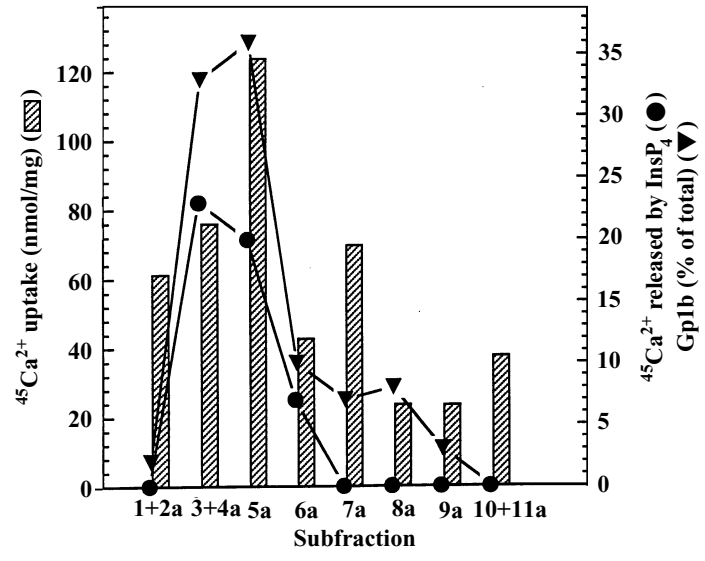

Figure 4 Phosphate-stimulated $\mathrm{Ca}^{2+}$ uptake by Gplb-containing membrane vesicle fractions 1a-6a and release of accumulated $\mathrm{Ca}^{2+}$ by $\operatorname{lns} P_{4}$

Membrane subfractions (1a-11a) loaded with calcium oxalate (but no ${ }^{45} \mathrm{Ca}^{2+}$ ) were washed and resuspended in medium with $10 \mathrm{mM}$ phosphate, $1 \mathrm{mM} \mathrm{ATP}$ and ${ }^{45} \mathrm{Ca}^{2+}$. $\boldsymbol{\nabla}$, GP1b content of $10 \mu \mathrm{g}$ membrane protein samples (average of three experiments). The bar graph represents ${ }^{45} \mathrm{Ca}^{2+}$ content of membrane vesicles, and 0 is the ${ }^{45} \mathrm{Ca}^{2+}$ released from membrane vesicles by $10 \mu \mathrm{M}$ Ins $P_{4}$ (average of three experiments). No $\mathrm{Ca}^{2+}$ was released from fractions 1a-6a by $10 \mu \mathrm{M} \operatorname{Ins} P_{3}$.

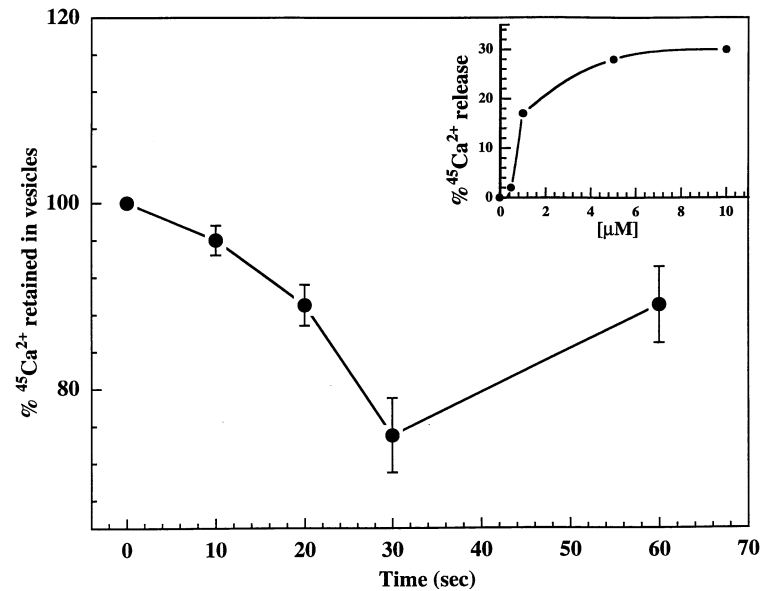

Figure $5 \mathrm{Ca}^{2+}$ release from pooled subfractions $3 \mathrm{a}-5 \mathrm{a}$ by $\operatorname{Ins} P_{4}$

Membrane subfractions $3 \mathrm{a}-5 \mathrm{a}$ ( $15 \mu \mathrm{g}$ of protein) were incubated in assay medium with $10 \mathrm{mM}$ phosphate, $1 \mathrm{mM} \mathrm{ATP}$ and ${ }^{45} \mathrm{Ca}^{2+}$ for $1 \mathrm{~h}$ as described in the Materials and methods section. The vesicles accumulated $77 \mathrm{nmol}$ of $\mathrm{Ca}^{2+} / \mathrm{mg}$ of protein, and $60 \%$ of the ${ }^{45} \mathrm{Ca}^{2+}$ was released by ionophore $\mathrm{A} 23187$. Ins $P_{4}$ was added and release of ${ }^{45} \mathrm{Ca}^{2+}$ was determined at the time points indicated. Data represent the means of four experiments. Inset: dose-response curve for $\mathrm{Ca}^{2+}$ release by $\operatorname{Ins} P_{4}$. Data are from a single experiment repeated four times with similar results.

pended in medium with $10 \mathrm{mM}$ phosphate, $1 \mathrm{mM}$ ATP and ${ }^{45} \mathrm{Ca}^{2+}$. Phosphate-stimulated $\mathrm{Ca}^{2+}$ uptake was greatest in the light subfractions $1 \mathrm{a}-7 \mathrm{a}$ that contained virtually all of the GpIb. Ins $P_{4}(10 \mu \mathrm{M})$ released $\mathrm{Ca}^{2+}$ from fractions $3 \mathrm{a}-6 \mathrm{a}$ (Figure 4$)$. The latter were slightly denser on the gradient than the original fractions 1-3 from which they were derived, possibly due to some small accumulation of calcium oxalate. Ins $P_{3}(10 \mu \mathrm{M})$ did not release ${ }^{45} \mathrm{Ca}^{2+}$ from fractions $3 \mathrm{a}-6 \mathrm{a}$, whereas Ins $P_{4}$ consistently released $15-30 \%$ of the vesicle ${ }^{45} \mathrm{Ca}^{2+}$ within $30 \mathrm{~s}$, and ionophore A23187 released $55 \%$ of the calcium (Figures 4 and 5 ). ${ }^{45} \mathrm{Ca}^{2+}$ release was maximal at $6 \mu \mathrm{M} \operatorname{Ins} P_{4}\left(\mathrm{EC}_{50}=0.6 \mu \mathrm{M}\right)$ (Figure 5, inset). Thapsigargin, an inhibitor of the internal membrane $\mathrm{Ca}^{2+}$ 


\section{Table 1 Purification of an Ins $P_{4}$ binding protein in human platelets}

Platelet membranes from fractions $1-3$ were isolated and solubilized as described in the Materials and methods section. Samples from each purification step were incubated with $10 \mathrm{nM}\left[^{3} \mathrm{H}\right] \mathrm{Ins} P_{4}$ (specific radioactivity $17 \mathrm{Ci} / \mathrm{mmol}$ ) and assayed for the amount of specific ligand binding to protein $(\mathrm{pmol} / \mathrm{mg})$. Data shown are from a single purification repeated three times with similar results.

\begin{tabular}{lllllr}
\hline Purification step & $\begin{array}{l}\text { Protein } \\
(\mathrm{mg})\end{array}$ & $\begin{array}{l}\text { Specific binding } \\
(\mathrm{pmol} / \mathrm{mg})\end{array}$ & $\begin{array}{l}\text { Total binding } \\
(\mathrm{pmol})\end{array}$ & $\begin{array}{l}\text { Yield } \\
(\%)\end{array}$ & \multicolumn{1}{c}{$\begin{array}{l}\text { Purification } \\
(\text { (fold })\end{array}$} \\
\hline Solubilized membranes & 69 & 0.46 & 32.4 & 100 & - \\
ConA-agarose flow-through & 28 & 0.48 & 13.7 & 42 & 24 \\
HPLC ion-exchange eluate & 0.340 & 12.8 & 4.3 & 13 & 12 \\
HPLC heparin-TSK eluate & 0.0075 & 532 & 3.9 & 1136 \\
\hline
\end{tabular}

ATPase [24], blocked ATP-dependent $\mathrm{Ca}^{2+}$ uptake by the DTS membranes (fractions $4+5$ ) and released $62 \%$ of the $\mathrm{Ca}^{2+}$ accumulated by this $\operatorname{Ins} P_{3}$-sensitive fraction. Thapsigargin also released $55 \%$ of accumulated ${ }^{45} \mathrm{Ca}^{2+}$ from the original fractions $1-3$, but failed to release any ${ }^{45} \mathrm{Ca}^{2+}$ from the $\operatorname{Ins} P_{4}$-sensitive fractions 1a-6a ( $n=3$ experiments).

The origin and orientation of vesicles exhibiting phosphatestimulated $\mathrm{Ca}^{2+}$ uptake and $\mathrm{Ca}^{2+}$ release by Ins $P_{4}$ was determined by labelling the surface proteins of intact platelets with sulphoNHS-LC-biotin. This reagent has the advantages of reactivity with free protein amino groups at neutral $\mathrm{pH}$ and an inability to penetrate the cell membrane, resulting in specific labelling of plasma membrane proteins with low background and high sensitivity compared with other protein labelling reagents [25]. The procedure, described in detail in the Materials and methods section, involved biotinylation of intact platelets, washing to remove unreacted reagent, membrane sonication, and the selective precipitation and removal by streptavidin-agarose beads of membrane vesicles labelled with biotin on their outer surfaces. The remaining membranes were loaded with calcium oxalate and centrifuged on a Percoll gradient to obtain $1.0 \mathrm{ml}$ subfractions designated $1 \mathrm{~b}-11 \mathrm{~b}$ and assayed for GpIb. Streptavidin-agarose beads (streptavidin concentration $<$ biotin concentration) removed a maximum of $40 \%$ of the GpIb-containing membranes from biotinylated platelets, but did not remove any GpIbcontaining membranes originating from platelets that had not been biotinylated. The remaining GpIb $(60 \%)$ that was not removed by streptavidin-agarose was contained in the 'light' fractions $1 b-5 b$ of the gradients. GpIb was not present in the denser calcium oxalate-loaded internal membrane subfractions 6b-11b. Although not removed by streptavidin-agarose, many proteins in membrane fractions $1 \mathrm{~b}-5 \mathrm{~b}$ were found to be labelled with biotin by Western blot analysis after SDS/PAGE (see the Materials and methods section). From these data we conclude that: (1) fractions $1 \mathrm{~b}-5 \mathrm{~b}$ were largely of plasma membrane origin, and (2) since they were not precipitated by streptavidinagarose beads, the biotin in them was oriented facing into the lumens of the vesicles, i.e. the membrane vesicles were inside-out. Subfractions $1 \mathrm{~b}-5 \mathrm{~b}$ took up ${ }^{45} \mathrm{Ca}^{2+}$ from the medium when incubated with $10 \mathrm{mM}$ phosphate plus ATP, and they released $15-35 \%$ of accumulated ${ }^{45} \mathrm{Ca}^{2+}$ when exposed to Ins $P_{4}$ (results not shown, similar to those in Figure 5).

Based on the evidence of specific and unique ligand binding sites for each of the inositol phosphates $\operatorname{Ins} P_{4}, \operatorname{Ins} P_{3}$ and $\operatorname{Ins} P_{6}$, we undertook the purification of the individual binding proteins. Using a radioactive ligand binding assay for detergent-solubilized receptors, three proteins were purified from platelet membrane fractions $1-3$ by a sequence of column chromatography steps. Isolation of the human platelet $\operatorname{Ins} P_{3}$ receptor is described elsewhere [22]. The scheme for purification of the Ins $P_{4}$ (Table 1)

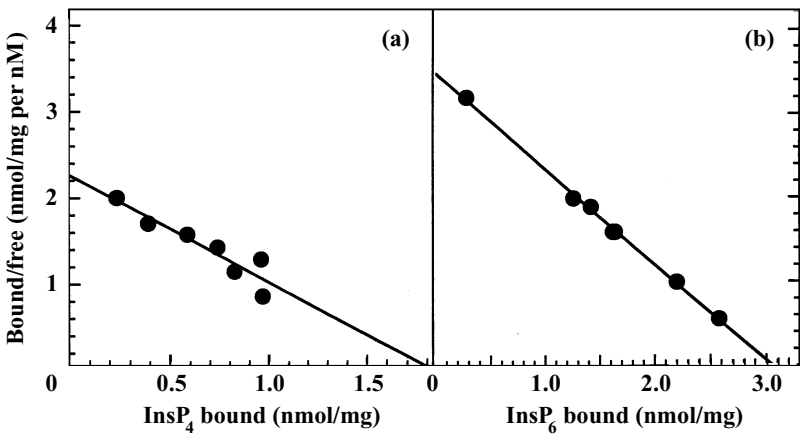

Figure $6\left[{ }^{3} \mathrm{H}\right] \mathrm{Ins} P_{4}$ and $\left[{ }^{3} \mathrm{H}\right] \mathrm{Ins} P_{6}$ binding to purified proteins

(a) Scatchard plot of $\left.{ }^{3} \mathrm{H}\right] \mathrm{Ins} P_{4}(5-50 \mathrm{nM})$ binding to $70 \mathrm{ng}$ of solubilized $104 \mathrm{kDa}$ protein. $B_{\max }=1.8 \mathrm{nmol} / \mathrm{mg}$ of protein; $K_{\mathrm{D}}=12 \mathrm{nM}$. (b) Scatchard plot of $\left[{ }^{3} \mathrm{H}\right] \mathrm{lns} P_{6}(5-75 \mathrm{nM})$ binding to $250 \mathrm{ng}$ of solubilized $116 \mathrm{kDa}$ protein fraction. $B_{\max }=3 \mathrm{nmol} / \mathrm{mg}$ of protein; $K_{\mathrm{D}}=5.9 \mathrm{nM}$.

and Ins $P_{6}$ binding proteins (see the Materials and methods section) employed a ConA-agarose column as the first step to remove membrane glycoproteins, followed by application of the flow-through fraction, containing all of the ligand binding activity, to an HPLC anion-exchange column. Both $\operatorname{Ins} P_{4}$ and Ins $P_{6}$ binding activities were adsorbed on to this column and were eluted by a salt gradient with a peak at $0.12 \mathrm{M} \mathrm{NaCl}$. The inositol phosphate binding fractions were concentrated and chromatographed on a heparin-TSK HPLC column. At pH 5.8 the $\left[{ }^{3} \mathrm{H}\right] \mathrm{Ins} P_{4}$ binding activity was adsorbed on to the column and was eluted by a salt gradient with a peak at $0.1 \mathrm{M} \mathrm{NaCl}$. The peak binding fractions were combined and concentrated. This fraction bound Ins $P_{4}$ with a $K_{\mathrm{D}}$ of $12 \mathrm{nM}$ and a $B_{\max }$ of $1.8 \mathrm{nmol} / \mathrm{mg}$ of protein (Figure 6), and contained a single polypeptide of molecular mass $104 \mathrm{kDa}$ by SDS/PAGE analysis (Figure 7).

All $\left[{ }^{3} \mathrm{H}\right] \operatorname{Ins} P_{6}$ binding activity was found in the flow-through fraction of the heparin-TSK column at $\mathrm{pH}$ 5.8, and was subsequently concentrated and further purified by gel filtration. $\left[{ }^{3} \mathrm{H}\right] \mathrm{Ins} P_{6}$ binding peaked in fractions which chromatographed with retention times intermediate between those of standards phosphorylase b $(97.5 \mathrm{kDa})$ and myosin $(206 \mathrm{kDa})$ that were chromatographed independently. The concentrated gel filtration fraction bound $\left[{ }^{3} \mathrm{H}\right] \operatorname{Ins} P_{6}$ with a $K_{\mathrm{D}}$ of $5.9 \mathrm{nM}$ and a $B_{\max }$ of $3 \mathrm{nmol} / \mathrm{mg}$ of protein at $\mathrm{pH} 7.4$ (Figure 6). There was no displacement of bound $\left[{ }^{3} \mathrm{H}\right] \operatorname{Ins} P_{6}$ (present at $10 \mathrm{nM}$ concentration) by $10 \mu \mathrm{M}$ Ins $P_{3}$, and only $20 \%$ displacement by $10 \mu \mathrm{M}$ Ins $P_{4}$. Heparin inhibited the binding of $10 \mathrm{nM}\left[{ }^{3} \mathrm{H}\right] \mathrm{Ins} P_{6}$ with an 


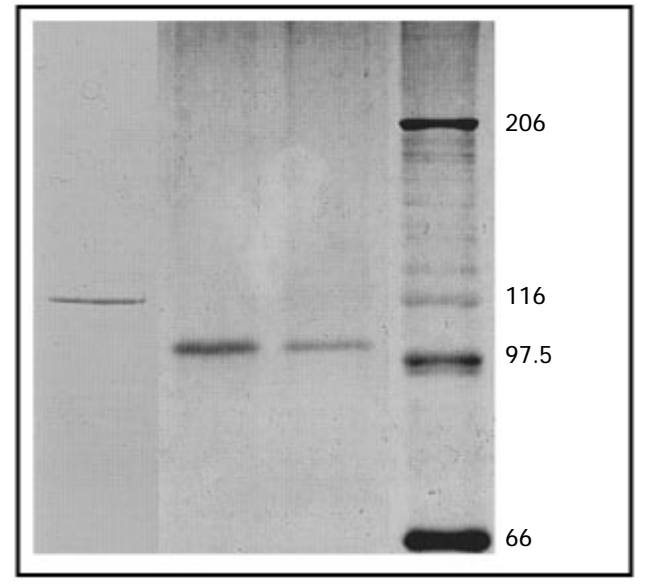

Figure 7 SDS/PAGE of purified $\operatorname{Ins} P_{4}$ and $\operatorname{Ins} P_{6}$ binding proteins from human platelets

Left lane, SDS/PAGE (7.5\% gels) of Ins $P_{6}$ binding fraction (1 $\mu \mathrm{g}$ of protein) isolated by HPLC gel filtration (colloidal Coomassie Blue stain). Middle lanes, SDS/PAGE $\left(7.5 \%\right.$ gels) of Ins $P_{4}$ binding fractions eluted from the heparin-TSK HPLC column (silver stain). Right lane, molecular mass markers (kDa): myosin, 206; $\beta$-galactosidase, 116; phosphorylase $b, 97.5$; BSA, 66 (positions indicated)

$\mathrm{IC}_{50}$ of $2 \mu \mathrm{M}$. The concentrated Ins $P_{6}$ binding fraction contained a single polypeptide band at $116 \mathrm{kDa}$ by SDS/PAGE analysis (Figure 7). Bands were cut from gels and analysed for total amino acid content and for sequences of protease-generated peptides. The amino acid composition matched that of $116 \mathrm{kDa}$ human vinculin [26], and two internal peptides (Val-Glu-Gly-IleGln-Ala-Ser-Val-Lys and Ala-Arg-Met-Gln-Glu-Ala-Met-ThrGln-Glu-Val) were identical to vinculin amino acids 658-666 and 585-595 respectively.

\section{DISCUSSION}

As part of an endeavour for the concurrent purification of the various inositol phosphate receptors of human platelets we isolated the solubilized $\operatorname{Ins} P_{3}$ receptor [22], and in the present paper we have described: (1) unique and specific ligand binding sites for $\operatorname{Ins} P_{4}$ and $\operatorname{Ins} P_{6}$, (2) the purification of a specific $\operatorname{Ins} P_{4}$ receptor protein, and (3) the preliminary identification and partial purification of a specific $\operatorname{Ins} P_{6}$ binding protein. Furthermore, we demonstrate that $\mathrm{Ins} P_{4}$ promotes the efflux of $\mathrm{Ca}^{2+}$ across inside-out plasma membrane vesicles, further substantiating its putative role as a second messenger that promotes $\mathrm{Ca}^{2+}$ influx into cells.

Our findings are in agreement with Cullen et al. [6-8], who established the localization of $\operatorname{Ins} P_{4}$ binding in the plasma membrane fraction of human platelets. Those membranes were isolated from neuraminidase-treated platelets by a sequence of sonication, density gradient centrifugation and high-voltage free flow electrophoresis. The surface membrane, depleted of negatively charged surface sialic acid, undergoes a cathodal shift during electrophoresis due the change in the membrane zeta potential [27]. During the sonication process membrane vesicles of either right-side-out or inside-out orientations can be formed, and the electrophoretic method isolates vesicles of both orientations.

In our studies, the establishment of $\operatorname{Ins} P_{4}$ binding and effects on $\mathrm{Ca}^{2+}$ permeability also required methods to separate elements of the internal membranes from the plasma-membrane-containing fractions. In these procedures we employed $\mathrm{GpIb}$ as a specific marker for the plasma membrane and took advantage of the different properties of the $\mathrm{Ca}^{2+}$ pumps of the plasma membrane and the internal membranes [23]. The plasma membrane fraction, unlike the internal membrane fraction, was reported not to transport calcium in the presence of oxalate [23], a property that is shared by plasma membrane $\mathrm{Ca}^{2+}$ pumps from other cells $[28,29]$. Therefore we obtained membrane fractions 1-3 that were enriched in the plasma membrane marker GpIb, but released $\mathrm{Ca}^{2+}$ in response to both $\operatorname{Ins} P_{4}$ and $\operatorname{Ins} P_{3}$. Our strategy was to load the membrane vesicles with $\mathrm{Ca}^{2+}$ plus oxalate, and then recentrifuge them on a Percoll gradient to separate the denser membranes containing calcium oxalate deposits (fractions 6a-11a) from the 'light' plasma membrane vesicles $(1 \mathrm{a}-5 \mathrm{a})$. The latter subfractions $(1 \mathrm{a}-5 \mathrm{a})$ contained all of the membrane GpIb, had a high specific activity for $\left[{ }^{3} \mathrm{H}\right] \mathrm{Ins} P_{4}$ binding and were capable of phosphate (but not oxalate)stimulated $\mathrm{Ca}^{2+}$ transport. These more purified plasma membrane vesicles released a substantial amount of their $\mathrm{Ca}^{2+}$ when exposed to $\operatorname{Ins} P_{4}\left(\mathrm{EC}_{50}=0.6 \mu \mathrm{M}\right)$, but showed little or no response to $\operatorname{Ins} P_{3}$ or $\operatorname{Ins} P_{6}$. Furthermore, thapsigargin was unable to affect $\mathrm{Ca}^{2+}$ uptake or to cause release of $\mathrm{Ca}^{2+}$ from the Ins $P_{4}$-sensitive membrane vesicles. In contrast, thapsigargin blocked ATPdependent $\mathrm{Ca}^{2+}$ uptake by the DTS membranes (fractions $4+5$ ) and released $62 \%$ of the $\mathrm{Ca}^{2+}$ accumulated by this Ins $P_{3}$-sensitive fraction. Thus the characteristics of the Ins $P_{4}$-sensitive membrane fractions were distinctly different from those of the internal membranes.

The denser, calcium oxalate-loaded, membrane fractions (7a-11a), derived from fractions $1-3$, contained the bulk of the total Ins $P_{4}$ binding activity $(90 \%)$, and all of the $\operatorname{Ins} P_{6}$ binding, but were devoid of GpIb. This finding suggests that $\operatorname{Ins} P_{4}$ receptors are present in at least two different membrane compartments, but an alternative explanation (discussed below) is that these compartments may be two subdomains of the plasma membrane. The $\operatorname{Ins} P_{6}$ receptor, on the other hand, appears to be entirely associated with one compartment that may be part of, or connected to, a major Ins $P_{4}$-receptor-containing compartment.

We consider three hypotheses that could account for these results. The first hypothesis holds that one compartment for Ins $P_{4}$ receptors is in the plasma membrane, and the other compartment, containing most of the $\operatorname{Ins} P_{4}$ receptors and all of the Ins $P_{6}$ receptors, is comprised of vesicles derived from internal DTS membranes that are capable of oxalate- and phosphatestimulated $\mathrm{Ca}^{2+}$ transport. The second hypothesis places all of the Ins $P_{4}$ and Ins $P_{6}$ receptors in the plasma membrane, with the bulk of them in the surface connected canalicular system (SCCS), and requires that the SCCS is devoid of GpIb and is capable of oxalate-stimulated $\mathrm{Ca}^{2+}$ transport. The SCCS is the site of the greatest cytochemically detectable $\mathrm{Ca}^{2+}$-ATPase activity in the plasma membrane [30], and it is possible that its properties differ from those of the plasma membrane $\mathrm{Ca}^{2+}$-ATPase activity described by Enouf et al. [23]; however, GpIb has been found in the SCCS [31], indicating that the second hypothesis is untenable. Lastly, the $\operatorname{Ins} P_{6}$ receptor and most of the $\operatorname{Ins} P_{4}$ receptors may be located in subdomains of the plasma membrane that are devoid of GpIb, adherent to regions of the DTS and tightly associated with each other even after sonication of whole platelets. Such plasma membrane-DTS complexes would become much denser when the DTS component is loaded with calcium oxalate, leading to their separation from vesicles that are derived purely from the plasma membrane. The SCCS, representing invaginations of the plasma membrane, may comprise this plasma membrane 
domain, since such an intimate association of DTS and SCCS membranes has been demonstrated by electron microscopy in intact platelets [32]. Further work is necessary to resolve these different possibilities.

The plasma membrane location of $\operatorname{Ins} P_{4}$ receptors and the $\mathrm{Ca}^{2+}$-releasing effect of $\operatorname{Ins} P_{4}$ were further established by biotinylation of platelet surface proteins with a reagent that does not penetrate the cells. After sonication of the platelets the membrane vesicles with biotin exposed on their surfaces (rightside-out vesicles) were removed with streptavidin-agarose beads. The remaining membranes were loaded with calcium oxalate and centrifuged on a density gradient to separate 'heavy' membrane vesicles from the 'light' membrane fractions $1 \mathrm{~b}-5 \mathrm{~b}$. The latter were largely plasma membrane vesicles, based on the fact that they contained all the GpIb, and they were in an inside-out orientation since, although not removed by streptavidin-agarose, they contained biotinylated proteins as shown by SDS/PAGE analysis. These fractions $1 \mathrm{~b}-5 \mathrm{~b}$ exhibited phosphate (but not oxalate)-stimulated active uptake of $\mathrm{Ca}^{2+}$, a plasma membrane property. These plasma membrane vesicles could release as much as one-third of their accumulated $\mathrm{Ca}^{2+}$ in response to $\operatorname{Ins} P_{4}$. Since the lumen of the inside-out plasma membrane vesicles represents the 'extracellular space', the action of $\operatorname{Ins} P_{4}$ is consistent with other findings that Ins $P_{4}$ promotes $\mathrm{Ca}^{2+}$ influx into cells $[9,12]$.

Proteins capable of selective high-affinity $\operatorname{Ins} P_{4}$ binding have been isolated from platelets and brain [7,14,33]. The purified $104 \mathrm{kDa} \operatorname{Ins} P_{4}$ binding protein of pig platelets [7] as well as that from human platelets is highly specific for $\operatorname{Ins}(1,3,4,5) P_{4}$ compared with other isomers, $\operatorname{Ins} P_{6}$ or $\operatorname{Ins} P_{3}$. $\left[{ }^{3} \mathrm{H}\right] \mathrm{Ins} P_{4}$ bound to the purified human platelet protein with a $K_{\mathrm{D}}$ of $12 \mathrm{nM}$ and $B_{\max }$ of $1.8 \mathrm{nmol} / \mathrm{mg}$ of protein, compared with values of $K_{\mathrm{D}}=$ $9.6 \mathrm{nM}$ and $B_{\max }=2.5$ and 6.0 obtained by Cullen et al. [8]. The predicted $B_{\max }$ is $9.6 \mathrm{nmol} / \mathrm{mg}$ of protein assuming one ligand binding site per molecule. In all respects, including the $\mathrm{pH}$ dependence for ligand binding [34], the human platelet protein appears to be identical to the $104 \mathrm{kDa}$ protein from pig platelet plasma membranes isolated by Cullen et al. [7]. These platelet proteins differ from all other putative $\operatorname{Ins} P_{4}$ binding proteins, such as the two fractions from brain with a high specific affinity for Ins $P_{4}$, which contained polypeptides of 182 plus $123 \mathrm{kDa}$ and 174 plus $84 \mathrm{kDa}$ respectively [14].

The platelet $104 \mathrm{kDa} \operatorname{Ins} P_{4}$ binding protein was recently identified as a member of the GAP family and designated GAP $1^{\text {IP4BP }}$ [8]. Important regions of this protein include a Lys/Arg-rich sequence in the $\mathrm{Ca}^{2+}$-independent phospholipid binding $\mathrm{C} 2 \mathrm{~B}$ domain, also found in GAP1 and GAP1 ${ }^{\mathrm{m}}$, which comprises the selective ligand binding site, a C2 $\mathrm{A} \mathrm{Ca}^{2+}$-dependent phospholipid binding domain, and a pleckstrin homology domain. GAP1 ${ }^{\mathrm{IP} 4 \mathrm{BP}}$ stimulated the GTPase activity of the lowmolecular-mass GTP-binding proteins H-Ras, R-Ras and Rap1A, but not K-Ras, Q61L, Rap3A or Rac. GTPase activation exerted on Ras (but not Rap1A) by GAP1 $1^{\mathrm{IP} 4 \mathrm{BP}}$ was inhibited by phospholipids commonly found in the inner leaflet of the plasma membrane, and this effect was reversed by $\operatorname{Ins} P_{4}$. Ins $P_{4}$ did not affect Rap or Rap-GAP interactions. Platelets contain members of the Ras-related family such as Rap1A, Rap1B, Rap2B, Rac1 and Ral [35]. Rap1B is present in the plasma membrane and SCCS [36] and is a prominent substrate for protein kinase A. Rap1B has been implicated in cAMP-stimulated $\mathrm{Ca}^{2+}$ transport by plasma membrane vesicles [37]. Since Ins $P_{4}$ increases the $\mathrm{Ca}^{2+}$ permeability of plasma membrane vesicles, it is possible that Ins $P_{4}-\mathrm{GAP} 1^{\mathrm{IP} 4 \mathrm{BP}}$, in conjunction with a small G-protein, controls the opening of a plasma membrane channel that is permeable to $\mathrm{Ca}^{2+}$. Indeed, this is also suggested by the finding that in $\mathrm{v}-\mathrm{Ki}$ ras-transformed $\mathrm{NIH} / 3 \mathrm{~T} 3$ cells, but not in control cells, the intracellular injection of $10 \mu \mathrm{M}$ Ins $P_{4}$ produced sustained $\mathrm{Ca}^{2+}$ oscillations requiring the presence of extracellular $\mathrm{Ca}^{2+}$ [38].

A number of proteins that bind inositol polyphosphates such as $\operatorname{Ins} P_{4}$ have an even higher affinity for $\operatorname{Ins} P_{6}$. Many of these proteins are involved in membrane cycling of secretory vesicles or clathrin-coated vesicles. Platelets contain clathrin which is associated with the plasma membrane, the SCCS and the surface of $\alpha$-granules [39], so it was important to also characterize the Ins $P_{6}$ binding proteins in platelets, and to discriminate between them and the specific $104 \mathrm{kDa} \operatorname{Ins} P_{4}$ binding protein. Ins $P_{6}$ binding proteins include $65 \mathrm{kDa}$ synaptotagmin II $[15,40]$, a synaptic vesicle membrane protein involved in exocytosis [41], and adaptins, which are components of the adaptor complexes that link clathrin to receptors in coated vesicles, i.e. the $\alpha$-subunit (AP-2, $\alpha$-c large chain, alpha adaptin) of the clathrin assembly heterotetramer protein AP-2 [42] and clathrin assembly protein 3 (AP-3, AP180). AP-2 cDNAs code for proteins of 108 and $104 \mathrm{kDa}$ [43], and were isolated from rat brain membranes as an Ins $P_{6}$ receptor complex of 115,105 and $50 \mathrm{kDa}$ polypeptides with $K_{\mathrm{D}}$ values for Ins $P_{6}$ of $12 \mathrm{nM}$ and $120 \mathrm{nM}$, and the same sequence of affinities as AP-3, i.e. $\operatorname{Ins} P_{6}>\operatorname{Ins} P_{5}>\operatorname{Ins} P_{4}>\operatorname{Ins} P_{3}$ [44]. AP-3 is a $91.4 \mathrm{kDa}$ protein from brain that runs anomalously at $155-185 \mathrm{kDa}$ by SDS/PAGE and has a $K_{\mathrm{D}}$ for $\operatorname{Ins} P_{6}$ of $1.2 \mu \mathrm{M}$ $[45,46]$. Some effects of inositol phosphates on the functions of these proteins have been described [45,47-49].

We identified a class of Ins $P_{6}$ binding sites in human platelet membranes with the relative affinities: $\operatorname{Ins} P_{6}>\operatorname{Ins} P_{5}>\operatorname{Ins} P_{4}>$ Ins $P_{3}$. By appropriate chromatographic methods the Ins $P_{6}$ binding activity was totally separated from the $104 \mathrm{kDa} \operatorname{Ins} P_{4}$ binding protein. The final purified Ins $P_{6}$ binding activity had a nominal molecular mass by gel filtration chromatography that was greater than $90 \mathrm{kDa}$, but less than $200 \mathrm{kDa}$, and contained one band of $116 \mathrm{kDa}$ by SDS/PAGE analysis. The protein bound $\left[{ }^{3} \mathrm{H}\right] \mathrm{Ins} P_{6}$ with a $K_{\mathrm{D}}$ of $5.9 \mathrm{nM}$ and a $B_{\max }$ of $3 \mathrm{nmol} / \mathrm{mg}$ of protein. The expected $B_{\max }$ for a $116 \mathrm{kDa}$ protein with one ligand binding site is $8.6 \mathrm{nmol} / \mathrm{mg}$ of protein, indicating that the $\operatorname{Ins} P_{6}$ binding activity was highly purified. The total amino acid composition of the protein band corresponded to the 1066 amino acids of 116732 Da human vinculin, and two peptides generated from the protein by proteolysis were identical to sequences in human vinculin [26].

Vinculin is a component of the platelet plasma membrane cytoskeleton [50] that may associate with the membrane through myristoylation or palmitoylation [51,52]. Although the C-terminus of vinculin is extremely basic [53], which might confer ligand binding properties comparable with those of the Arg/Lysrich inositol polyphosphosphate binding regions in GAP $1^{\text {IP4BP }}$ and synaptotagmin II, its ability to bind $\operatorname{Ins} P_{6}$ has not been reported previously. However, we cannot rule out the possibility that the actual $\operatorname{Ins} P_{6}$ binding protein is another component of similar molecular mass that co-purified with vinculin, such as the heavy chain of AP-2. Further work is required to fully establish the identity of the high-affinity $\operatorname{Ins} P_{6}$ binding protein in platelets.

In conclusion, human platelet plasma membranes contain a specific Ins $P_{4}$ binding protein of apparent molecular mass $104 \mathrm{kDa}$ and a specific Ins $P_{6}$ binding protein with an apparent molecular mass of $116 \mathrm{kDa}$. Inside-out plasma membrane vesicles containing the Ins $P_{4}$ receptor accumulated $\mathrm{Ca}^{2+}$ in the presence of phosphate anion and ATP, and they released a significant portion of that $\mathrm{Ca}^{2+}$ when exposed to submicromolar concentrations of $\operatorname{Ins} P_{4}$, but not $\operatorname{Ins} P_{3}$ or $\operatorname{Ins} P_{6}$. This effect is consistent with other findings indicating that $\operatorname{Ins} P_{4}$ can act as a second messenger to increase the $\mathrm{Ca}^{2+}$ permeability of the plasma membrane and permit entry of $\mathrm{Ca}^{2+}$ from the extracellular space. This action of $\operatorname{Ins} P_{4}$ may be a significant mechanism in platelets 
to account for the influx of $\mathrm{Ca}^{2+}$ that occurs subsequent to agonist-induced production of $\operatorname{Ins} P_{3}$ and its release of internal $\mathrm{Ca}^{2+}$ stores [54].

This work was supported by NIH grants HL 18937 and HL 42454-05 and by grants from the American Heart Association and the University of Connecticut Research Foundation.

\section{REFERENCES}

1 Theibert, A., Supattapone, S., Worley, P., Baraban, J., Meek, J. and Snyder, S. (1987) Biochem. Biophys. Res. Commun. 3, 1283-1289

2 Reiser, G., Schafer, R., Donie, F., Hulser, E., Nehls-Sahabandu, M. and Mayr, G. (1991) Biochem. J. 280, 533-539

3 Bradford, P. and Irvine, R. (1987) Biochem. Biophys. Res. Commun. 149, 680-685

4 Enyedi, P. and Williams, G. (1988) J. Biol. Chem. 263, 7940-7942

5 Koppler, P., Mersel, M. and Malviya, A. (1994) Biochemistry 33, 14707-14713

6 Cullen, P., Patel, Y., Kakkar, V., Irvine, R. and Authi, K. (1994) Biochem. J. 298, 739-742

7 Cullen, P., Dawson, A. and Irvine, R. (1995) Biochem. J. 305, 139-143

8 Cullen, P., Hsuan, J., Truong, O., Letcher, A., Jackson, T., Dawson, A. and Irvine, R. (1995) Nature (London) 376, 527-530

9 Irvine, R. and Moor, R. (1986) Biochem. J. 240, 917-920

10 Joseph, S., Hansen, C. and Williamson, J. (1989) Mol. Pharmacol. 36, 391-397

11 Hill, T., Dean, M. and Boynton, L. (1988) Science 242, 1176-1178

12 Luckhoff, A. and Clapham, D. (1992) Nature (London) 355, 356-358

13 Chadwick, C., Timerman, A., Saito, A., Mayrleitner, M., Schindler, H. and Fleischer, S. (1992) J. Biol. Chem. 267, 3473-3481

14 Theibert, A., Estevez, V., Mourey, R., Marecek, J., Barrow, R., Prestwich, G. and Snyder, S. (1992) J. Biol. Chem. 267, 9071-9079

15 Niinobe, M., Yamaguchi, Y., Fukuda, M. and Mikoshiba, K. (1994) Biochem. Biophys. Res. Commun. 205, 1036-1042

16 O'Rourke, F., Halenda, S., Zavoica, G. and Feinstein, M. (1985) J. Biol. Chem. 260, 956-962

17 O'Rourke, F. and Feinstein, M. (1990) Biochem. J. 267, 297-302

18 Authi, K. and Crawford, N. (1985) Biochem. J. 230, 247-253

19 White, G., II, Barton, D., White, T. and Fischer, T. (1989) Thromb. Res. 56, 575-581

20 Authi, K. (1992) FEBS Lett. 298, 173-176

21 Hughes, A. and Putney, J. (1990) J. Environ. Health Perspect. 84, 141-147

22 O'Rourke, F., Matthews, E. and Feinstein, M. (1995) Biochem. J. 312, 499-503

23 Enouf, J., Bredoux, R., Bourdeau, N. and Levy-Toledano, S. (1987) J. Biol. Chem. 262, 9293-9297

24 Papp, B., Enyedi, A., Kovacs, T., Sarkadi, B., Wuytack, F., Thastrup, O., Gardos, G., Bredoux, R., Levy-Toledano, S. and Enouf, J. (1991) J. Biol. Chem. 266, 14593-14596

25 Lantz, L. and Holms, K. (1995) Biotechniques. 18, 56-58
26 Weller, P., Ogryzko, E., Corben, E., Zhidkova, N., Patel, B., Price G., Spurr, N. Koteliansky, V. and Critchley, D. (1990) Proc. Natl. Acad. Sci. U.S.A. 87, 5667-5671

27 Crawford, N. (1985) in Cell Electrophoresis (Schutt, W. and Klinkmann, H., eds.), pp. 225-246, Walter de Gruyter \& Co., Berlin

28 Grover, A. (1985) Cell Calcium. 6, 227-236

29 Mickelson, J., Beaudry, T. and Louis, C. (1985) Arch. Biochem. Biophys. 242, $127-136$

30 Cutler, L., Rodan, G. and Feinstein, M. (1978) Biochim. Biophys. Acta 542, 357-371

31 Escolar, G., Clemetson, K. and White, J. (1994) J. Lab. Clin. Med. 123, 536-546

32 White, J. (1971) Am. J. Pathol. 66, 295-311

33 Donie, F. and Reiser, G. (1991) Biochem. J. 275, 453-457

34 Cullen, P. (1995) FEBS Lett. 358, 240-242

35 Manning, S. and Brass, L. (1991) Thromb. Haemostasis 66, 393-399

36 Berger, G., Quarck, R., Levy-Toledano, S., deGunzburg, J. and Cramer, E. (1994) Br. J. Haematol. 88, 372-382

37 Corvazier, M., Enouf, J., Papp, B., de Gunzburg, J., Tavitian, A. and Levy-Toledano, S. (1992) Biochem. J. 281, 325-331

38 Hashii, M., Nozawa, Y. and Higashida, H. (1993) J. Biol. Chem. 268, 19403-19410

39 Klinger, M. and Kluger, H. (1995) Cell Tissue Res. 279, 453-457

40 Fukuda, M., Aruga, J., Niinobe, M., Aimoto, S. and Mikoshiba, K. (1994) J. Biol. Chem. 269, 29206-29211

41 Perin, M., Fried, V., Mignery, G., Jahn, R. and Sudhof, T. (1990) Nature (London) 345, 260-263

42 Voglmaier, S., Keen, J., Murphy, J., Ferris, C., Prestwich, G., Snyder, S. and Theibert, A. ( 1992) Biochem. Biophys. Res. Commun. 187, 158-163

43 Robinson, M. (1989) J. Cell Biol. 108, 833-842

44 Theibert, A., Estevez, V., Ferris, C., Danoff, S., Barrow, R., Prestwich, G. and Snyder, S. (1991) Proc. Natl. Acad. Sci. U.S.A. 88, 3165-3169

45 Norris, F., Ungewickell, E. and Majerus, P. (1995) J. Biol. Chem. 270, 214-217

46 Morris, S., Schroder, S., Plessman, U., Weber, K. and Lafer, E. (1995) J. Biol. Chem. 270, 1564-1568

47 Ye, W., Bembenek, M., Shears, S. and Lafer, E. (1995) J. Biol. Chem. 270. 1564-1568

48 Kijima, Y., Mayrleitner, M., Timerman, A., Saito, A., Schindler, H. and Fleischer, S. (1993) J. Biol. Chem. 268, 16253-16258

49 Timerman, A., Mayrleitner, M., Lukas, T., Chadwick, C., Saito, A.,Watterson, D., Schindler, H. and Fleischer, S. (1992) Proc. Natl. Acad. Sci. U.S.A. 89, 8976-8980

50 Fox, J., Lipfert, L., Clark, E., Reynolds, C., Austin, C. and Brugge, J. (1993) J. Biol. Chem. 268, 25973-25984

51 Coutu, M. and Craig, S. (1988) Proc. Natl. Acad. Sci. U.S.A. 85, 8535-8539

52 Fausser, J., Ungewickell, E., Ruch, J. and Lesot, H. (1993) J. Biochem. (Tokyo) 114, 498-503

53 Strasser, P., Gimona, M., Herzog, M., Geiger, B. and Small, J. (1993) FEBS Lett. 317, 189-194

54 Doni, M., Cavallini, L. and Alexandre, A. (1994) Biochem. J. 303, 599-605 